\title{
Trends in Business Markets
}

\author{
Rajdeep Grewal $^{1}$ - Gary L. Lilien ${ }^{2}$
}

Published online: 24 June 2015

(C) Springer Science+Business Media New York 2015

While commerce between firms, i.e., business or B2B markets is roughly comparable in monetary terms to the commerce between firms and consumers (B2C), the volume of highquality academic research devoted to issues in B2B pales in comparison to that focused on B2C. ${ }^{1}$ Our goal with this special issue is a focus on important new research in this understudied domain.

The special issue comprises four articles-a perspective piece, which we coauthored with several of our esteemed colleagues, and three research articles. Our overview piece lays out our thoughts on the agenda for research in business markets, so we will keep this introduction brief. (Note that in line with journal policy, the articles appear in alphabetical order based on the last name of the first author of the article).

The first article in the special issue is the perspective piece by Grewal et al. that lays out challenges and opportunities associated with understanding and managing buying behavior in B2B markets. The authors identify four trends that are affecting the nature of $\mathrm{B} 2 \mathrm{~B}$ buying and the associated research needs: the changing landscape of B2B buying, the increasing sophistication of buyers, the impact of technological changes, and the increasing impact and growth of emerging markets. For each of these trends, the authors provide an overview of the domain, a conceptual framework and a research agenda.

Next, Mahr, Rindfleisch, and Slotegraaf examine the importance of creative and deliberate problem-solving styles in

\section{Rajdeep Grewal}

grewalr@unc.edu

1 Kenan-Flagler Business School, The University of North Carolina, Chapel Hill, NC 27599, USA

2 Smeal College of Business, Pennsylvania State University, State College, PA 16801, USA increasing the success of crowdsourcing platforms to solve innovation-related problems. Based on dual-processing theory, the authors use survey and archival data to show how the success of creative and deliberate problem-solving styles varies depending on the amount of time invested and familiarity of context.

In the third article, Sridhar, Voorhees, and Gopalakrishna study business trade shows with a focus on short- and longterm outcomes of lead generation and sales conversion. The authors use attendee-level data from several trade shows of Fortune 500 firms to show how key outcomes are driven by pre-, at-, and post-show marketing efforts.

In the final paper, Yim, Josephson, Johnson, and Sisodiya study the link between innovation and the influence of interfirm relational strategies, i.e., relational proclivity and relational capability as well as the influence of interfirm relational traits, i.e., information flow and relational embeddedness. The authors also conceptualize that marketing and R\&D intensities moderate the influence of interfirm relational traits on innovation outcomes. Using primary and secondary data from a sample of firms in the high-tech industry, the authors provide support for their theoretical framework.

Special issues like this one require dedication of valuable time from reviewers and we would like to acknowledge those important contributions; we are grateful to the following individuals for their helpful, constructive reviews:

Arnaud De Bruyn (ESSEC Business School)

Abbie Griffin (University of Utah)

Christopher Groening (Kent State University)

Alok Kumar (University of Nebraska)

Girish Mallapragada (Indiana University)

Gaia Rubera (Bocconi University)

Alok Saboo (Georgia State University)

Johanna Slot (Pennsylvania State University) 
Robert Spekman (University of Virginia)

Raji Srinivasan (University of Texas at Austin)

Kapil Tuli (Singapore Management University)
We also wish to acknowledge the support that the Institute for the Study of Business Markets (ISBM; see www.isbm.org) provided for this special issue. 